\title{
ŞANLIURFA YÖRESİNE ÖZGÜ TIRNAKLI (DÜZ) EKMEKTE BAZI KATKI MADDELERINIIN KULLANIMININ EKMEK KALİTESİNE ETKİSİ
}

\author{
Mehmet Köten ${ }^{1 *}$, Ahmet Sabri Ünsal ${ }^{2}$ \\ ${ }^{1}$ Kilis 7 Aralık Üniversitesi, Yusuf Şerefoğlu Sağılk Bilimleri Fakültesi, Beslenme ve Diyetetik Bölümü, Kilis, \\ Türkiye \\ ${ }^{2}$ Harran Üniversitesi, Mühendislik Fakültesi, Gıda Mühendisliği Bölümü, Şanlıurfa, Türkiye
}

Geliş / Received: 25.10.2019; Kabul / Accepted: 28.04.2020; Online bask1 / Published online: 09.05.2020

Köten, M., Ünsal, A.S. (2020). Şanlıurfa yöresine özgü tırnaklı (düz) ekmekte bazı katkı maddelerinin kullanımının ekmek kalitesine etkisi. GIDA (2020) 45(3) 473-484 doi: 10.15237/gida.GD19137

Köten, M., Ünsal, A.S. (2020). The effect of using some additives on bread quality of "tirnakli (flat) ekmek" native to Şanliurfa. GIDA (2020) 45(3) 473484 doi: 10.15237/gida.GD19137

\section{ÖZ}

Bu çalısmada Şanlıurfa yöresine özgü “Tırnaklı (düz) Ekmek”te bazı katkı maddelerinin kullanımının ekmek kalitesine etkileri araştırlmışır. Bu amaçla, buğday ununa \%10, 20,30 oranlarında durum buğday unu (A), \%0.3, 0.6, 0.9 oranlarında DATEM (monogliseridlerin diasetil tartarik asit esterleri) (B) ve $25,50,75 \mathrm{mg} / \mathrm{kg}$ C vitamini (C) katılarak tırnaklı ekmek üretilmiş ve ekmekler 48 saat süreyle depolanmıştır. Çalışmada, katkılı unlarda farinograf ve ekstensograf özellikler ile depolamanın 1.24. ve 48. saatlerinde ekmeklerde nem ve duyusal özellikler belirlenmiştir. Elde edilen sonuçlara göre, katkıların farinografta su absorbsiyonu, stabilite süresi, yumuşama derecesi ve yoğurma tolerans sayısı üzerine etkisi önemli $(p<0.05)$ bulunurken, gelişme süresi üzerine etkisi önemsiz ( $p>0.05$ ) bulunmuştur. Oran artışına bağlı olarak katkıların askorbik asit hariç ekstensografta maksimum direnci artırdığ gözlenmiştir. Tüm depolama saatlerinde katkı kullanılarak üretilen ekmekler kontrole göre daha yüksek nem değerine sahip olmuştur. Depolama süresi boyunca tüm katkılı ekmeklerin tekstür ve tat-aroma puanları azalmışır.

Anahtar kelimeler: Ekmek katkı maddeleri, düz ekmek, ekmek kalitesi, depolama

\section{THE EFFECT OF USING SOME ADDITIVES ON BREAD QUALITY OF “TIRNAKLI (FLAT) EKMEK" NATIVE TO SANLIURFA}

\begin{abstract}
In this study, the effects of some additives on quality of "Tirnaklı Ekmek", a common flat type bread in Sanliurfa province, were investigated. For this purpose, tirnaklı ekmek was produced by adding 10, 20, $30 \%$ durum wheat flour (A), 0.3, 0.6, 0.9\% DATEM (diacetyl tartaric acid esters of monoglycerides) (B), and $25,50,75 \mathrm{mg} / \mathrm{kg}$ vitamin $\mathrm{C}(\mathrm{C})$ to wheat flour and the breads were stored for 48 hours. In the study, the farinograph and extensograph properties of mixed flours, and the moisture and sensory properties of breads were determined at 1 st, 24th and 48th hours of storage. According to the results, the effects of using additives on water absorption, stability time, mixing tolerans index and softening degree were significant $(p<0.05)$, but not significant $(p>0.05)$ on the development time. Results of extensographic measurements show that increasing levels of all additives improved the maximum resistance against extensograph, except for the ascorbic acid. At every stage of the storage, mixed breads had higher moisture values than the control. During of storage period, the texture and taste-aroma scores of all the breads with additive addition decreased.
\end{abstract}

Keywords: Bread additives, flat bread, bread quality, storage

*Yazışmalardan sorumlu yazar/Corresponding author

$\triangle$ mehmetkoten@gmail.com,

(c) (+90) 5337655569

圆 (+90) 3488139392

Mehmet Köten; ORCID no: 0000-0002-8232-8610

Ahmet Sabri Ünsal; ORCID no: 0000-0002-8012-3208 


\section{GİRİ̧̧}

Ekmek tüketimi, pirinç tüketiminin çok olduğu Doğu Asya ülkeleri dişında, Avrupa, Orta Doğu ülkeleri, Kuzey Afrika ve Amerika başta olmak üzere dünya genelinde oldukça yaygındır (Cingöz, 2018). Tahila dayalı beslenmenin hâkim olduğu Türkiye, kişi başına ekmek tüketiminde dünyada ilk sırada yer almaktadır (Demir vd., 2009).

Kültürel alışkanlıklara ve kullanılan teknolojilere bağlı olarak dünyanın birçok ülkesinde çok farklı tipte ekmek yapılmaktadır. Tüketilen ekmeklerin büyük bölümünü francala tip ekmekler oluşturmasına karşın yöresel ekmeklerin tüketimi de oldukça fazladır. Bunlar arasında yer alan düz ekmekler, ülkemizin yanı sıra birçok Orta Doğu ve Kuzey Afrika ülkelerinde yaygin olarak tüketilmektedir. Düz ekmekler batı tipi ekmekler de denilen yüksek hacimli tava ekmeklerinden farklı özelliklere sahiptir. Bu özelliklerden birkaçı düşük spesifik hacimli, yüksek kabuk ve düşük ekmek içi oranlarına sahip olmaları ve ayrıca yenilirken ağızda bıraktıkları yapıskanımsı yapının hissedilmesi olarak sayılabilir. Bu farklılıkların asıl nedeni düz ekmeklerin batı tipi tava ekmeklerine göre daha kısa fermantasyon süresine sahip olması ve daha yüksek pişirme sıcaklığı ile oluşan farklı geleneksel üretim koşullarıdır (Köten ve Ünsal, 2007).

Şanliurfa ve yöresinde tüketimi oldukça yüksek düzeyde olan "tırnaklı ekmek" de düz ekmekler içerisinde yer almaktadır. Taze pişmiş trrnaklı ekmek yumuşak, esnek ve elastiktir. Ögünlük tüketilmek üzere alınan turnaklı ekmek, hemen yenmezse birkaç saat içinde bayatlayıp sertleşebilmektedir.

Ekmeğin depolanması sırasında meydana gelen bayatlama olayı, sadece nişasta retrogradasyonu ve nem kaybiyla değil ayrıca polimerlerin tekrar oluşumu ve suyun transferiyle de alakalı olan son derece kompleks bir prosestir. Bu durumu önlemek ya da en aza indirgemek için yapılan uygulamalar arasinda en bilinenleri firincilik ürünlerine bayatlamayı önleyici katk1 maddeleri ilave etmektir (Sungur, 2018).
Türk Gıda Kodeksi Gıda Katk1 Maddeleri Yönetmeliği'nde ekmek üretiminde kullanılmasina izin verilen diğer bileşenler; antimikrobiyal maddeler (kalsiyum propiyanat, sorbik asit vb.), emülgatörler, stabilizatörler, süt ve süt ürünleri (peynir altı suyu tozu, süt tozu vb.), tatlandırıcılar (sakkaroz, glikoz vb.), oksidanlar (askorbik asit), yağlar ve enzimler ( $\alpha$ amilaz, hemiselülaz, glikoz oksidaz, lipaz, proteaz vb.) olarak sinıflandirilmaktadir (Anonymous, 2013).

$\mathrm{Bu}$ katk1 maddelerinden DATEM (monogliseridlerin diasetil tartarik asit esterleri), yağ1 seven (lipofilik) ve suyu seven (hidrofilik) iki gruptan oluşan yüzey aktif (sürfektant, emülgatör) madde olarak tanımlanmaktadır. Emülsiyon stabilitesini artırarak hamurun yapısını kuvvetlendirici, ekmek içi yapısını iyileştirici ve yumuşatıcı olarak da kullanılmaktadır (Gaupp ve Adams, 2014).

Hamurun ve ekmeğin niteliğini düzeltmek amaciyla kullanilan C vitamini, gluten yapisını kuvvetlendirirken hamurun işlenebilmesini de arturmaktadır. Una $C$ vitamini katılmasıyla ekmek yapısının gelişmesi, hamurun dinlenme süresinin kısalması, hamurun olgunlaşmasının hizlanması, hamur ve ekmek hacminin artışı, gözeneklerde incelik ve homojenlik gibi gelişmeler gözlenmiştir (Dizlek ve Gül, 2007).

Makarnalık buğdaylardan elde edilen unlarda (durum buğday unu) daha fazla zedelenmiş nişasta oluşmaktadır. Zedelenmiş nişasta miktarının yüksek olması yoğurma sırasında unun daha fazla su almasına yol açmaktadır. Unun yoğurma sirasinda fazla su almasi, birim undan elde edilecek ekmek ağırlığı, kabuk yumuşaklığ1 ve ekmeğin raf ömrü bakımından oldukça önemlidir (Ma vd., 2016). Bu nedenle bu tip unlann ekmek yapımında bir katkı maddesi olarak kullanılması ile ekmeğin bayatlamasını geciktireceği düşünülmektedir.

Ekmeğin beslenmedeki önemi ile tırnaklı ekmeğin Şanliurfa ve yöresinde beğeniyle yoğun bir şekilde tüketimi göz önünde bulundurularak planlanan bu çalışmada, DATEM, C vitamini ve durum buğday ununun hamurun reolojik özelliklerine, tırnaklı ekmeğin bayatlama göstergesi olan su içeriğine ve 
duyusal özelliklerine etkileri araştırllmıştır. Türkiye'de tüketimi oldukça yüksek düz ekmekler konusunda az sayıda çalışma olmasına rağmen Şanliurfa ve yöresine özgü tırnaklı düz ekmek konusunda yapılmış herhangi bir çalş̧maya rastlanmamıştır. Bu bağlamda bu çalışmanın özgün bir çalışma niteliği taşıdığı söylenebilir.

\section{MATERYAL ve YÖNTEM}

\section{Materyal}

Çalışmada, Adana ilinde faaliyet gösteren ÖZKAR Un Fabrikası San. Ltd. Ști.'den temin edilen ekmeklik buğday unu kullanılmıştır. Ekmek üretiminde kullanılan pres yaş maya ve rafine kristal tuz piyasadan temin edilmiştir. Ekmek formülasyonunda toz haldeki Beldem marka DATEM (monogliseridlerin diasetil tartarik asit esterleri) ve Roche marka $C$ vitamini (L-askorbik asit) kullanılmışır. Ayrıca formülasyona ilave edilen durum buğday unu ise Ankara Tarla
Bitkileri Merkez Araşturma Enstitüsü'nden temin edilmiştir.

\section{Yöntem}

Araşturmada kullanılan deneme deseni Çizelge 1'de gösterilmiştir. Buna göre formülasyonlar1 birbirinden farklı 10 ayr1 tırnaklı ekmek üretilmiştir. Bu amaçla, ekmeklik buğday ununa $\% 10,20,30$ oranlannda durum buğday unu (A), $\% 0.3, \quad 0.6, \quad 0.9$ oranlarında DATEM (monogliseridlerin diasetil tartarik asit esterleri) (B) ve $25,50,75 \mathrm{mg} / \mathrm{kg}$ düzeylerinde $\mathrm{C}$ vitamini (L-askorbik asit) (C) kattlarak tırnaklı ekmek üretilmiş ve ekmekler 48 saat süreyle oda sicaklı̆̆ında şeffaf poşetler içerisinde depolanmışır. Tüm formülasyonlarda her $100 \mathrm{~g}$. un+katk1 maddesi karışımı için farinograf cihazında belirlenen su miktarının 5 birim üstünde su (56.6 mL ile $62.8 \mathrm{~mL}$ arasinda) kullanılırken, 3 g maya ve $1.5 \mathrm{~g}$ tuz kullanılmıştır.

Çizelge 1. Ekmek formülasyonuna ilave edilen bileşenler ve kullanım oranları Table 1. Components added to bread formulation and usage rates

\begin{tabular}{|c|c|c|c|c|c|c|c|c|c|c|}
\hline $\begin{array}{l}\text { Bileşenler } \\
\text { Components }\end{array}$ & $\begin{array}{c}\text { Kontrol } \\
\text { Control }\end{array}$ & \multicolumn{3}{|c|}{$\begin{array}{l}\mathrm{A}^{*}(\%) \\
(\%) A^{*}\end{array}$} & \multicolumn{3}{|c|}{$\begin{array}{l}\mathrm{B}^{* *}(\%) \\
(\%) B^{* *}\end{array}$} & \multicolumn{3}{|c|}{$\begin{array}{l}\mathrm{C}^{* * *}(\mathrm{mg} / \mathrm{kg}) \\
C^{* * *}(\mathrm{mg} / \mathrm{kg})\end{array}$} \\
\hline $\begin{array}{l}\text { Kullanim } \\
\text { miktar1 } \\
\text { Amount of } \\
\text { usage }\end{array}$ & 0 & 10 & 20 & 30 & 0.3 & 0.6 & 0.9 & 25 & 50 & 75 \\
\hline
\end{tabular}

${ }^{*} \mathrm{~A}$ : Durum buğday unu, ${ }^{* *} \mathrm{~B}$ : DATEM, ${ }^{* * *} \mathrm{C}$ : L-Askorbik asit (C vitamini)

${ }^{*}$ A: Durum wheat flour, ${ }^{* *} B: D A T E M,{ }^{* * *} C: L$-Ascorbic acid (vitamin C)

Ekmek denemeleri, tırnaklı (düz) ekmek üretiminin yapıldığı yerel bir firında gerçekleștirilmiștir. Ekmekler, una farklı oranlarda DATEM (B), C vitamini (C) ve durum buğday unu (A) ilave edildikten sonra bu firındaki tırnaklı ekmek üretim yöntemi uygulanarak elde edilmiştir. Ekmek yapımında kullanılan un karışımlant ve diğer hammaddeler hamur yoğurucuda optimum hamur kıvamı elde edilinceye kadar yoğrulmuştur (10-15 dk). Hamur yapiminda kullanilan su sicaklığ $20 \pm 2^{\circ} \mathrm{C}$ olacak şekilde ayarlanmıştır. Ardından hamura yaklaşık 40 dakika, \%80 nispi nem ve $32^{\circ} \mathrm{C}^{\prime}$ de kitle fermantasyonu uygulanmıştur. Fermantasyon sonunda hamur 230 gr olacak şekilde yumaklar haline getirilip 2. fermantasyona birakılmıştır $(\sim 15$ dakika). Daha sonra yumak şeklindeki hamurlar yaklaşık $70-80 \mathrm{~cm}$ uzunluk, $25-30 \mathrm{~cm}$ en ve $1-1.5$ cm kalınlığında düz bir şekle getirilip el ile üst yüzeye tırnaklama isslemi yapıldıktan ve özel karışım (\%20 un ve \%80 sudan oluşan bulamaç) sürüldükten sonra $300-350{ }^{\circ} \mathrm{C}$ 'deki taş firında $2-3$ dakika pişirilmiştir. Pişme işleminin ardından ekmekler 10 dakika süre ile bez örtü arasında oda sıcaklığına soğutulup analize alınmıştır. Ekmeklerdeki bayatlama 1, 24, 48 saat sonra yapılan nem ölçümleriyle değerlendirilmiştir.

\section{Kimyasal analizler}

Buğday unu ve ekmek örneklerinin nem (metod 44-19), kül (metod 08-01) ve protein (metod içeriklerinin belirlenmesinde AACC metotları kullanılmıstır (AACC, 2002). 


\section{Fizikokimyasal analizler}

Tırnaklı ekmek üretiminde kullanılan buğday ununun yaş gluten, kuru gluten ve gluten indeks (metod 38-12) değerleri AACC metoduna göre belirlenmiştir (AACC, 2002). Yaş gluten, gluten yıkama cihazında (Yücebaş Glutamatik, Türkiye) elde edildikten sonra bu amaçla geliştirilen cihazda santrifüjlenerek (Yücebaş Gluten indeks, Türkiye) gluten indeks değerleri belirlenmiştir. Yaş gluten, glutork cihazında kurutulup (Yücebaş Glutork, Türkiye) desikatörde soğutulduktan sonra tartılmıs ve böylece kuru gluten değerleri elde edilmiştir. Ayrıca unda yapılan Zeleny sedimantasyon analizi ise ICC standart no: 116 metodu kullanılarak gerçekleştirilmiştir (ICC, 2002).

\section{Farinograf analizleri}

Su absorpsiyonu, hamur gelişme süresi, hamur stabilite süresi, yumuşama tolerans sayısı ve yumuşama derecesi değerleri AACC metod no: 54-21'e göre Brabender marka farinograf cihazında belirlenmiştir (AACC, 2002).

\section{Ekstensograf analizleri}

Uzamaya karşı direnç $\left(\mathrm{R}_{5}\right)$, uzamaya karş1 maksimum direnç $\left(R_{m}\right)$, uzama yeteneği $(E)$ ve ekstensogram alanı (A) değerleri AACC metod no: 54-10'a göre Brabender marka ekstensograf cihazında belirlenmiş (AACC, 2002) ve 135. dakikada çizilen kurvelerin ortalaması alınarak değerlendirme yapılmıştır.

\section{Duyusal analizler}

Duyusal analizler Harran Üniversitesi Ziraat Fakültesi Gıda Mühendisliği Bölümü’nde Basman ve Köksel (1999, 2001), Qarooni vd. (1993) ve Farvili vd. (1995) tarafindan tanımlanan kriterler modifiye edilerek düzenlenen formlann kullanılması suretiyle 10 kissiden oluşan panalist grubu tarafindan gerçekleştirilmiştir. Panelistler örnekleri görünüş, tekstür, tat ve aroma özellikleri bakımından 1 ile 5 puan aralığında değerlendirmeye almıştır.

\section{İstatistiksel analizler}

Tesadüf parselleri deneme planında faktöriyel dizaynına göre deneme kurulmuştur. Sonuçların değerlendirilmesinde SPSS paket programı kullanılmıstır (SPSSinc., 1998). Ortalama değerlerin karşılaştırulması LSD testine göre MSTAT-C paket programında yapılmıs ve $\% 5$ güven sınırına göre birbirinden farksız bulunan değerler çizelgelerde aynı harflerle gösterilmiştir.

\section{SONUÇ ve TARTIŞMA \\ Tirnaklı Ekmek Üretiminde Kullanılan Unların ve Un+Katkı Maddeleri Karışımlarının Bazı Özellikleri}

Tirnaklı ekmek üretiminde hammadde olarak kullanılan ekmeklik unun ve bir katkı maddesi olarak kullanilan durum buğday ununun bileşimine ait değerler Çizelge 2'de verilmiştir. Çizelge 2'nin incelenmesiyle de görülebileceği gibi, çalışmada kullanılan un örneğinin kül ve protein dışında diğer tüm özellik değerlerinin Türk G1da Kodeksine (Anonymous, 2013) uygun olduğu tespit edilmiştir. Durum buğday ununda saptanan özelliklere ait değerlerin de literatürle (Sayaslan vd., 2018; Pasqualone vd., 2017; Kaur vd., 2015; Torbica vd., 2011; Hatcher vd., 2009) uyum içerinde olduğu görülmüştür.

Tirnaklı ekmek üretiminde kullanılan farklı düzeylerde katkı içeren un karışımlarının farinograf özelliklerine ait değerler Çizelge 3'de verilmiştir. Çizelgede görüldüğü gibi katkıl1 unların su absorbsiyonları farklllık göstermiştir. Genel olarak bakıldığında DATEM (B) ve C vitamini (C) katkılarının su absorbsiyonlarını kontrole göre düşürdüğü görülmüştür. Durum buğday unu (A) katkısının \%10 düzeyinde kullanıldığ1 örnekte su absorbsiyonu kontrole göre yüksek bulunmasına karşın diğer düzeylerinde farklılık görülmemiştir. Su absorbsiyonu üzerine katk1 ve katk1 düzeylerinin etkisi önemli bulunmuştur $(p<0.01)$. Katk1 kullanımının gelişme süresi üzerine etkisi önemsiz bulunmuştur $(p>0.05)$.

Stabilite süresi özellikle durum buğday unu (A) kullanımı ile önemli derecede artarken \%0.9 DATEM (B) kullanımı ile azalmıştır. Yoğurma tolerans sayısı DATEM (B) kullanımı ile artmış diğer katkıların kullanımı ile düşmüştür. Yoğurma tolerans sayısı üzerine sadece katkı çeşidinin etkili olduğu bulunmuştur $(p<0.05)$. Yumuşama derecesi değerlerinde ise özellikle $C$ vitamininin (C) kullanıldığ1 un örneklerinde kontrole göre önemli derecede artış söz konusu olmuştur 
$(p<0.05)$. Stabilite süresi hamurun işlemeye karş1 dayanıklılığnın bir göstergesi olarak değerlendirilmektedir. Stabilite süresi ne kadar uzun ise unun ekmeklik kalitesi de o ölçüde iyidir (Coşkuner, 1993). Çizelge 3’ten de görülebileceği gibi oran artsşına paralel olarak durum buğday unu (A) ve DATEM (B) katkılarının kullanıldığ1 örneklerde yumuşama derecesi değerlerinin düştüğü, C vitamininin (C) kullanıldığı örneklerde ise arttığ1 saptanmiştır. Ancak DATEM (B) kullanımı ile yumuşama derecesi değerlerindeki düşüş istatistiksel olarak önemsiz $(p>0.05)$ bulunmuştur. Yumuşama derecesi de kalite ile ilgili bir un özelliğidir. Yüksek yumuşama derecesine sahip unlarda fermantasyon süresi kisa tutulmalı ve hamur kısa sürede işlenmelidir. Aksi durumlarda hamur çok çabuk yumuşamakta ve kıvamını kaybetme eğilimi göstermektedir (Uluöz, 1965). Farklı araşturmacilar tarafindan yapılan çalışmalarda da (Al-Hamdani vd., 2019; Baratto vd., 2015; Ding ve Yang, 2013; Baiano ve Terracone, 2011; Sungur ve Ercan, 2011; Xiujin vd., 2007; Aamodt vd., 2003; Çelik vd., 2000; Ravi vd., 2000); una DATEM veya $C$ vitamini ilavesi ve ilave edilen katkı oranının artışına bağlı olarak farinograf değerlerinde çalışmamıza yakın ve benzer sonuçlar bulunmuştur.

Çizelge 2. Araşurmada kullanılan un örneklerinin bazı özellikleri

Table 2. Some characteristics of the flour samples used in study

\begin{tabular}{|c|c|c|c|c|c|c|c|}
\hline \multirow[b]{2}{*}{$\begin{array}{l}\text { Örnek } \\
\text { Sample }\end{array}$} & \multicolumn{7}{|c|}{$\begin{array}{c}\text { Özellikler } \\
\text { Characteristics }\end{array}$} \\
\hline & $\begin{array}{l}\text { Nem } \\
\text { Moistu } \\
\text { re (\%) }\end{array}$ & $\begin{array}{l}\text { Kül } \\
\text { Ash } \\
(\%)^{*}\end{array}$ & $\begin{array}{l}\text { Protein } \\
\text { Protein } \\
(\%)^{* 1}\end{array}$ & $\begin{array}{c}\text { Yaş } \\
\text { gluten } \\
\text { Wet gluten } \\
(\%)\end{array}$ & $\begin{array}{c}\text { Kuru } \\
\text { gluten } \\
\text { Dry gluten } \\
(\%)\end{array}$ & $\begin{array}{l}\text { Düşme sayisı } \\
\text { Falling number } \\
\quad \text { (sn) }\end{array}$ & $\begin{array}{l}\text { Sedimentasyon } \\
\text { Sedimentation } \\
(\mathrm{ml})\end{array}$ \\
\hline $\begin{array}{l}\text { Ekmeklik un } \\
\text { Bread flour }\end{array}$ & 11.13 & 0.62 & 7.94 & 28.30 & 9.68 & 324.50 & 26.60 \\
\hline $\begin{array}{l}\text { Durum buğday unu } \\
\text { Durum wheat flour }\end{array}$ & 11.02 & 0.92 & 13.80 & 32.82 & 10.98 & 205.50 & 38.32 \\
\hline
\end{tabular}

${ }^{*}$ Kuru maddede hesaplanmışır, ${ }^{1} \mathrm{~F}=5.7$ alınmıştır

${ }^{*}$ Calculated in dry matter, ${ }^{1} \mathrm{~F}: 5.7$ were taken

Tirnaklı ekmek üretiminde kullanılan farklı düzeylerde katkı içeren un karıșımlarının ekstensograf özelliklerine ait değerler Çizelge 4'te verilmiştir. 135. dakikada çizilen ekstensogram eğrisi temel alınarak yapılan değerlendirmeye göre katk1 ve katkı düzeyleri tüm ekstensograf değerleri üzerine önemli $(\phi<0.01) \quad$ derecede etki göstermiştir. Farklı katkıların kullanılmasıyla hazırlanan karışımlardan hamurun uzamaya karşı gösterdiği maksimum direnç $\left(\mathrm{R}_{\mathrm{m}}\right)$ ve hamurun sabit deformasyondaki direnci $\left(R_{5}\right)$ katılan katk1 düzeylerine bağlı olarak özellikle durum buğday unu (A) ve DATEM (B) katkılarının en düşük seviyelerinde kontrolden daha düşük veya aynı çıarken diğer seviyelerinde önemli derecede yükselmiştir. DATEM (B) katkısının $\% 0.6$ ve C vitamininin (C) $25 \mathrm{mg} / \mathrm{kg}$ kullanıldığ1 örnekler dışında katkılar, ekstensogram alanını (enerji değeri) kullanım oranlarına bağlı olarak kontrole göre artırarak olumlu etkide bulunmuş ve en yüksek dozlarında en yüksek enerji değerleri elde edilmiştir.

Hamurun uzamaya karşı dirençli olması unun gluteninin kuvvetli olduğunun göstergesi olup hamurun dayanma derecesini ifade etmekte ve gluten miktar ve kalitesiyle ilgili olmaktadır (Rasper ve Preston, 1991). Hamurun uzama yeteneği işlenebilme yeteneği ile ilgili olup özellikle düz ekmek yapımında kullanilacak unlarda uzama yeteneğinin yüksek olması buna karşın uzamaya karşı gösterilen direncin de nispeten düşük olması istenmektedir (Coşkuner, 1993). Çalışmamızdan elde edilen sonuçlarla uyumlu olarak farklı araştırmacılar da (AlHamdani vd., 2019; Ding ve Yang, 2013; Baiano ve Terracone, 2011; Sungur ve Ercan, 2011; Xiujin vd., 2007; Aamodt vd., 2003; Ravi vd., 2000; Çelik vd., 2000; ) çalışmalarında benzer ve yakın ekstensograf değerlerini tespit etmişlerdir. 
Çizelge 3. Farklı düzeylerde katkı içeren un karışımlarının farinograf değerleri Table 3. Farinograph values of flour mixtures containing different levels of additive

\begin{tabular}{|c|c|c|c|c|c|c|}
\hline $\begin{array}{l}\text { Katk1lar* } \\
\text { Additives }\end{array}$ & $\begin{array}{l}\text { Katk1 } \\
\text { düzeyi } \\
\text { Additive } \\
\text { level }\end{array}$ & $\begin{array}{c}\text { Su absorbsiyonu } \\
\text { Water absorption } \\
(\%)\end{array}$ & $\begin{array}{c}\text { Gelişme } \\
\text { süresi } \\
\text { Development } \\
\text { time } \\
\text { (d; minute) }\end{array}$ & $\begin{array}{c}\text { Stabilite } \\
\text { süresi } \\
\text { Stability time } \\
\text { (d; minute) }\end{array}$ & $\begin{array}{c}\text { Yoğurma } \\
\text { tolerans say1s1 } \\
\text { Mixing tolerance } \\
\text { index } \\
(\mathrm{BU})^{1} \\
\end{array}$ & $\begin{array}{c}\text { Yumuşama } \\
\text { derecesi } \\
\text { Degree of softening } \\
(\mathrm{BU})^{1}\end{array}$ \\
\hline \multirow[t]{2}{*}{$\begin{array}{l}\text { Ekmeklik un } \\
\text { Bread flour }\end{array}$} & 0.0 & $54.00 \pm 0.00^{\mathrm{b}(* *)}$ & $1.19 \pm 0.00$ & $1.80 \pm 0.33^{\mathrm{e}}$ & $56.90 \pm 0.00^{\mathrm{a}}$ & $100.00 \pm 0.00^{\mathrm{b}}$ \\
\hline & 10 & $54.55 \pm 0.07 \mathrm{a}$ & $1.33 \pm 0.25$ & $3.12 \pm 0.69^{\mathrm{cd}}$ & $52.63 \pm 8.27^{\mathrm{ab}}$ & $96.50 \pm 4.95^{b}$ \\
\hline \multirow[t]{3}{*}{$\mathrm{A}(\%)$} & 20 & $53.85 \pm 0.07^{b}$ & $1.29 \pm 0.09$ & $5.03 \pm 0.53^{b}$ & $46.78 \pm 16.54^{\mathrm{ab}}$ & $81.86 \pm 0.00^{\mathrm{cd}}$ \\
\hline & 30 & $53.90 \pm 0.14^{b}$ & $1.31 \pm 0.05$ & $6.90 \pm 0.85^{a}$ & $35.09 \pm 8.27 \mathrm{~b}$ & $73.10 \pm 4.14^{\mathrm{d}}$ \\
\hline & 0.3 & $53.45 \pm 0.07 \mathrm{c}$ & $1.13 \pm 0.04$ & $1.76 \pm 0.52^{\mathrm{e}}$ & $54.65 \pm 19.30^{a}$ & $99.41 \pm 8.27 \mathrm{~b}$ \\
\hline \multirow[t]{3}{*}{ B $(\%)$} & 0.6 & $53.40 \pm 0.00 \mathrm{~cd}$ & $1.21 \pm 0.01$ & $2.18 \pm 0.11 \mathrm{de}$ & $61.40 \pm 4.14^{\mathrm{a}}$ & $84.79 \pm 4.14 c$ \\
\hline & 0.9 & $53.20 \pm 0.00^{\mathrm{e}}$ & $1.31 \pm 0.06$ & $1.92 \pm 0.05^{\mathrm{e}}$ & $65.60 \pm 4.38^{\mathrm{a}}$ & $75.00 \pm 0.00^{\mathrm{d}}$ \\
\hline & 25 & $53.25 \pm 0.07 \mathrm{de}$ & $1.18 \pm 0.03$ & $3.12 \pm 0.47^{\mathrm{cd}}$ & $49.70 \pm 4.13^{\mathrm{ab}}$ & $102.78 \pm 3.93^{\mathrm{ab}}$ \\
\hline \multirow[t]{2}{*}{$\mathrm{C}(\mathrm{mg} / \mathrm{kg})$} & 50 & $53.20 \pm 0.00^{\mathrm{e}}$ & $1.32 \pm 0.05$ & $3.37 \pm 0.21^{\mathrm{c}}$ & $46.78 \pm 8.27 \mathrm{ab}$ & $105.56 \pm 0.00^{\mathrm{ab}}$ \\
\hline & 75 & $53.50 \pm 0.14^{c}$ & $1.32 \pm 0.05$ & $3.49 \pm 0.37 \mathrm{c}$ & $52.62 \pm 0.00^{\mathrm{ab}}$ & $111.61 \pm 8.55^{\mathrm{a}}$ \\
\hline
\end{tabular}

*A: Durum buğday unu, B: DATEM, C: L-Askorbik asit (C vitamini)

*A: Durum wheat flour, B: DATEM, C: L-Ascorbic acid (vitamin C)

${ }^{* *}$ Çizelgede, her bir özellik için sütunlar yukarıdan aşağıya doğru incelendiğinde aynı harflerle gösterilen değerler istatistiksel olarak birbirinden farksizdır $(p>0.05)$

${ }^{*}$ When the columns are examined from top to bottom for each property in the table, the values indicated by the same letters are statistically different from each other $(p>0.05)$

${ }^{1}$ Brabender Ünitesi ${ }^{1}$ Brabender Units

Çizelge 4. Farklı düzeylerde katkı içeren un karışımlarının ekstensograf değerleri

Table 4. Extensograph values of flour mixtures containing different levels of additive

\begin{tabular}{lccccc}
\hline $\begin{array}{l}\text { Katk1lar* } \\
\text { Additives }\end{array}$ & $\begin{array}{c}\text { Katk1 } \\
\text { düzeyi } \\
\text { Additive } \\
\text { level }\end{array}$ & $\begin{array}{c}\text { Direnç } \\
\text { Resistance } \\
\left(\mathrm{R}_{5}\right)(\mathrm{BU})^{1}\end{array}$ & $\begin{array}{c}\text { Uzama yeteneği } \\
\text { Extensibility } \\
(\mathrm{mm})\end{array}$ & $\begin{array}{c}\text { Maksimum direnç } \\
\text { Maximum resistance } \\
\left(\mathrm{R}_{\mathrm{m}}\right)(\mathrm{BU})^{1}\end{array}$ & $\begin{array}{c}\text { Enerji değeri } \\
\text { Energy value } \\
\left(\mathrm{cm}^{2}\right)\end{array}$ \\
\hline $\begin{array}{l}\text { Ekmeklik un } \\
\text { Bread flour }\end{array}$ & 0.0 & $471.50 \pm 28.99^{\mathrm{de}(* *)}$ & $108.50 \pm 4.95^{\mathrm{abcd}}$ & $529.50 \pm 28.99 \mathrm{~cd}$ & $82.00 \pm 0.00^{\mathrm{cd}}$ \\
& 10 & $462.50 \pm 21.92^{\mathrm{def}}$ & $122.00 \pm 2.83^{\mathrm{a}}$ & $534.50 \pm 12.02^{\mathrm{cd}}$ & $95.00 \pm 0.00^{\mathrm{ab}}$ \\
$\mathrm{A}(\%)$ & 20 & $490.50 \pm 31.82^{\mathrm{cd}}$ & $112.50 \pm 16.26^{\mathrm{abc}}$ & $553.50 \pm 14.85^{\mathrm{bc}}$ & $88.50 \pm 13.44^{\mathrm{abcd}}$ \\
& 30 & $571.00 \pm 14.14^{\mathrm{b}}$ & $107.00 \pm 2.83^{\mathrm{bcd}}$ & $653.00 \pm 14.14^{\mathrm{a}}$ & $96.50 \pm 2.12^{\mathrm{a}}$ \\
& 0.3 & $468.00 \pm 24.04^{\mathrm{de}}$ & $116.50 \pm 10.61^{\mathrm{ab}}$ & $533.00 \pm 14.14^{\mathrm{cd}}$ & $90.00 \pm 7.07^{\mathrm{abc}}$ \\
$\mathrm{B}(\%)$ & 0.6 & $526.00 \pm 14.14^{\mathrm{bc}}$ & $97.50 \pm 4.95^{\mathrm{d}}$ & $589.50 \pm 36.06^{\mathrm{b}}$ & $78.00 \pm 8.49^{\mathrm{d}}$ \\
& 0.9 & $625.50 \pm 33.23^{\mathrm{a}}$ & $101.00 \pm 0.00^{\mathrm{cd}}$ & $692.00 \pm 41.01^{\mathrm{a}}$ & $94.50 \pm 3.54^{\mathrm{ab}}$ \\
& 25 & $464.50 \pm 33.23^{\mathrm{def}}$ & $109.00 \pm 5.66^{\mathrm{abcd}}$ & $521.00 \pm 31.11^{\mathrm{cde}}$ & $80.50 \pm 0.71^{\mathrm{cd}}$ \\
& 50 & $413.50 \pm 4.95^{\mathrm{f}}$ & $120.00 \pm 0.00^{\mathrm{ab}}$ & $471.50 \pm 9.19^{\mathrm{e}}$ & $84.00 \pm 1.41^{\mathrm{bcd}}$ \\
& 75 & $432.00 \pm 2.83^{\mathrm{ef}}$ & $118.00 \pm 2.83^{\mathrm{ab}}$ & $483.00 \pm 7.07 \mathrm{de}$ & $85.00 \pm 2.83^{\mathrm{bcd}}$ \\
\hline
\end{tabular}

*A: Durum buğday unu, B: DATEM, C: L-Askorbik asit (C vitamini)

*A: Durum wheat flour, B: DATEM, C: L-Ascorbic acid (vitamin C)

${ }^{* *}$ Çizelgede, her bir özellik için sütunlar yukarıdan aşağıya doğru incelendiğinde aynı harflerle gösterilen değerler istatistiksel olarak birbirinden farksızdır $(p>0.05)$

** When the columns are examined from top to bottom for each property in the table, the values indicated by the same letters are statistically different from each other $(p>0.05)$

${ }^{1}$ Brabender Ünitesi ${ }^{1}$ Brabender Units 
Tirnaklı Ekmeklerde Depolama Süresince Saptanan Nem Değerleri

Ekmeklerin firından çıtıktan sonra 1, 24 ve 48 saat sonra ölçülen $\%$ nem içeriklerine ilişkin değerler Çizelge 5’te verilmiştir. Katkıların $p<0.05$ düzeyinde, depolama süresinin ise $p<0.01$ düzeyinde ekmeklerin nem değerleri üzerinde etkili olduğu belirlenmiştir. Çizelge incelendiğinde kontrolle birlikte tüm örneklerin nem değerlerinde depolama boyunca düşüş görülmüştür.

Çizelge 5. Ekmeklerin depolama süresince saptanan nem değerleri Table 5. Moisture values determined during storage of breads

\begin{tabular}{|c|c|c|c|c|}
\hline \multirow{2}{*}{$\begin{array}{l}\text { Katkilar* } \\
\text { Additives }\end{array}$} & \multirow{2}{*}{$\begin{array}{l}\text { Katk1 düzeyi } \\
\text { Additive level }\end{array}$} & \multicolumn{3}{|c|}{$\begin{array}{c}\text { Depolama süresi (saat) } \\
\text { Storage time (hour) }\end{array}$} \\
\hline & & 1 & 24 & 48 \\
\hline \multirow[t]{2}{*}{$\begin{array}{l}\text { Kontrol } \\
\text { Control }\end{array}$} & 0.0 & $25.78 \pm 1.60^{\mathrm{bA}(* *)}$ & $24.61 \pm 2.57 \mathrm{bB}$ & $23.71 \pm 2.07 \mathrm{bC}$ \\
\hline & 10 & $26.90 \pm 1.48^{\mathrm{aA}}$ & $26.71 \pm 0.30^{a \mathrm{~B}}$ & $26.61 \pm 1.03^{\mathrm{aC}}$ \\
\hline \multirow[t]{3}{*}{ A $(\%)$} & 20 & $26.92 \pm 0.48^{\mathrm{aA}}$ & $26.73 \pm 0.41^{\mathrm{aB}}$ & $26.10 \pm 0.41 \mathrm{aC}$ \\
\hline & 30 & $26.97 \pm 3.41^{\mathrm{aA}}$ & $26.80 \pm 0.41^{\mathrm{aB}}$ & $25.92 \pm 0.83^{\mathrm{aC}}$ \\
\hline & 0.3 & $25.98 \pm 0.76^{\mathrm{abA}}$ & $26.38 \pm 0.81^{\mathrm{abB}}$ & $23.24 \pm 1.71^{\mathrm{abC}}$ \\
\hline \multirow[t]{3}{*}{ B $(\%)$} & 0.6 & $26.50 \pm 0.10^{\mathrm{abA}}$ & $26.04 \pm 2.30^{\mathrm{abB}}$ & $24.21 \pm 1.16^{\mathrm{abC}}$ \\
\hline & 0.9 & $27.65 \pm 0.98^{\mathrm{abA}}$ & $26.60 \pm 1.34 \mathrm{abB}$ & $25.80 \pm 2.28 \mathrm{abC}$ \\
\hline & 25 & $26.69 \pm 1.68^{\mathrm{bA}}$ & $24.43 \pm 0.16^{\mathrm{bB}}$ & $24.20 \pm 1.41^{b C}$ \\
\hline \multirow[t]{2}{*}{$\mathrm{C}(\mathrm{mg} / \mathrm{kg})$} & 50 & $24.07 \pm 1.44 \mathrm{bA}$ & $24.08 \pm 0.85^{\mathrm{bB}}$ & $24.00 \pm 3.32^{\mathrm{bC}}$ \\
\hline & 75 & $25.39 \pm 1.22^{\mathrm{bA}}$ & $25.58 \pm 1.70^{\mathrm{bB}}$ & $24.71 \pm 3.92^{\mathrm{bC}}$ \\
\hline
\end{tabular}

${ }^{*} \mathrm{~A}$ : Durum buğday unu, B: DATEM, C: L-Askorbik asit (C vitamini)

* A: Durum wheat flour, B: DATEM, C: L-Ascorbic acid (vitamin C)

${ }^{* *}$ Çizelgede, her bir katkı çeşidi için aynı sütunda aynı küçük harflerle gösterilen değerler istatistiksel olarak birbirinden farksızdır $(p>0.05)$, Depolama süresine göre, sütunlar soldan sağa doğru incelendiğinde aynı büyük harflerle gösterilen değerler istatistiksel olarak birbirinden farksızdır $(p>0.05)$

${ }^{* *}$ In the table, the values indicated by the same small letters in the same column for each additive type are statistically different from each other ( $\left.p>0.05\right)$, When the columns are examined from left to right according to storage time, the values shown with the same uppercase letters are statistically different from each other $(p>0.05)$

Ekmekler arasında en yüksek nem içeriğine \%27.65) ilk yapılan ölçümde \%0.9 DATEM (B) katkısı kullanılarak yapılan ekmeklerin, en düşük nem içeriğine $(\% 23.24)$ ise 48 . saatte yapılan ölçümlerde \%0.3 DATEM (B) katkısı kullanılarak yapılan ekmeklerin sahip olduğu saptanmıştır.

Genel olarak değerlendirildiğinde durum buğday unu (A) katkılı örnekler depolama süresi boyunca daha yüksek nem değerlerine sahip olmuş ve nem düzeylerinde daha az düşüş olmuştur. Özer ve Atlan (1995), bazı katk1 maddeleri kullanarak yaptıkları küçük ekmeklerde nem değerinin depolama boyunca düştüğünü bildirmişlerdir. Toufeili vd. (1995), arap ekmeği üzerine yaptıkları araşturmalarında DATEM'in artan oranlarda ilavesiyle ekmeklerin nem düzeyinin arttığını ifade etmişlerdir. Yine farklı araştırmacıların DATEM ve C vitamini katk1l ekmeklerde yaptkkları çalışmalarda çalışmamızda elde ettiğimiz nem değerlerine yakın değerler bulunmuştur (Akın, 2015; Dizlek vd., 2013; Karatekin, 2008; Dizlek ve Gül, 2007).

\section{Tirnaklı Ekmeklerde Depolama Süresince Elde edilen Duyusal Özellik Değerleri}

Tirnaklı ekmeklerde 5 tam puan üzerinden değerlendirilmek üzere görünüş özelliğine ait duyusal analiz, depolamanin 1. saattinde; tekstür ve tat-aroma özelliklerine ait duyusal analizler ise depolamanin 1., 24 . ve 48 . saatlerinde gerçekleştirilmiştir. Elde edilen veriler Çizelge 6'da gösterilmiştir. 
Çizelge 6. Ekmeklerin depolama süresince saptanan duyusal özellik değerleri Table 6. Sensory property values determined during storage of breads

\begin{tabular}{|c|c|c|c|c|}
\hline \multirow{2}{*}{$\begin{array}{l}\text { Katkilar* } \\
\text { Additives }\end{array}$} & \multirow{2}{*}{$\begin{array}{l}\text { Katk1 düzeyi } \\
\text { Additive level }\end{array}$} & \multicolumn{3}{|c|}{$\begin{array}{c}\text { Depolama süresi (saat) } \\
\text { Storage time (hour) }\end{array}$} \\
\hline & & 1 & 24 & 48 \\
\hline \multicolumn{5}{|c|}{$\begin{array}{l}\text { Görünüş puanları } \\
\text { Appearance scores }\end{array}$} \\
\hline \multirow[t]{2}{*}{$\begin{array}{l}\text { Kontrol } \\
\text { Control }\end{array}$} & 0.0 & $4.05 \pm 0.01^{\mathrm{ab}(* *)}$ & - & - \\
\hline & 10 & $3.86 \pm 0.42^{\mathrm{b}}$ & - & - \\
\hline \multirow[t]{3}{*}{$\mathrm{A}(\%)$} & 20 & $4.54 \pm 0.03^{\mathrm{a}}$ & - & - \\
\hline & 30 & $4.52 \pm 0.02^{\mathrm{a}}$ & - & - \\
\hline & 0.3 & $4.39 \pm 0.28^{\mathrm{ab}}$ & & - \\
\hline \multirow[t]{3}{*}{ B $(\%)$} & 0.6 & $4.28 \pm 0.06^{\mathrm{ab}}$ & - & - \\
\hline & 0.9 & $4.35 \pm 0.02^{\mathrm{ab}}$ & & - \\
\hline & 25 & $3.84 \pm 0.76^{\mathrm{b}}$ & - & - \\
\hline \multirow[t]{3}{*}{$\mathrm{C}(\mathrm{mg} / \mathrm{kg})$} & 50 & $4.30 \pm 0.20^{\mathrm{ab}}$ & & - \\
\hline & 75 & $4.25 \pm 0.15^{\mathrm{ab}}$ & - & - \\
\hline & & $\begin{array}{l}\text { Tekstür puanları } \\
\text { Texture scores }\end{array}$ & & \\
\hline \multirow[t]{2}{*}{$\begin{array}{l}\text { Kontrol } \\
\text { Control }\end{array}$} & 0.0 & $3.87 \pm 1.00^{\mathrm{aA}(* *)}$ & $2.85 \pm 0.27 \mathrm{aB}$ & $2.55 \pm 0.07 \mathrm{aC}$ \\
\hline & 10 & $4.19 \pm 0.71^{\mathrm{aA}}$ & $3.13 \pm 0.31^{\mathrm{aB}}$ & $2.65 \pm 0.21^{\mathrm{aC}}$ \\
\hline \multirow[t]{3}{*}{$\mathrm{A}(\%)$} & 20 & $4.50 \pm 0.04^{\mathrm{aA}}$ & $3.07 \pm 0.22^{\mathrm{aB}}$ & $2.89 \pm 0.20^{\mathrm{aC}}$ \\
\hline & 30 & $4.27 \pm 0.47 \mathrm{aA}$ & $3.43 \pm 0.11^{\mathrm{aB}}$ & $2.68 \pm 0.299^{\mathrm{aC}}$ \\
\hline & 0.3 & $4.09 \pm 0.06^{\mathrm{aA}}$ & $3.24 \pm 0.78^{\mathrm{aB}}$ & $3.03 \pm 0.33^{\mathrm{aC}}$ \\
\hline \multirow[t]{3}{*}{ B $(\%)$} & 0.6 & $4.40 \pm 0.25^{\mathrm{aA}}$ & $3.26 \pm 0.26^{\mathrm{aB}}$ & $2.74 \pm 0.20^{\mathrm{aC}}$ \\
\hline & 0.9 & $4.69 \pm 0.08^{\mathrm{aA}}$ & $2.99 \pm 0.47 \mathrm{aB}$ & $2.39 \pm 0.11^{\mathrm{aC}}$ \\
\hline & 25 & $4.21 \pm 0.02^{\mathrm{abA}}$ & $3.13 \pm 0.18^{\mathrm{abB}}$ & $2.50 \pm 0.44^{\mathrm{abC}}$ \\
\hline \multirow[t]{3}{*}{$\mathrm{C}(\mathrm{mg} / \mathrm{kg})$} & 50 & $3.96 \pm 0.06^{\mathrm{abA}}$ & $2.68 \pm 0.33 \mathrm{abB}$ & $2.57 \pm 0.04^{\mathrm{abC}}$ \\
\hline & 75 & $3.65 \pm 0.25^{\mathrm{abA}}$ & $3.16 \pm 0.54 \mathrm{abB}$ & $2.79 \pm 0.35^{\mathrm{abC}}$ \\
\hline & & $\begin{array}{l}\text { Tat-aroma puanlar1 } \\
\text { Taste-aroma scores }\end{array}$ & & \\
\hline \multirow[t]{2}{*}{$\begin{array}{l}\text { Kontrol } \\
\text { Control }\end{array}$} & 0.0 & $4.16 \pm 0.75^{\mathrm{A}(* *)}$ & $3.16 \pm 0.23^{\mathrm{B}}$ & $2.43 \pm 0.33^{C}$ \\
\hline & 10 & $4.33 \pm 0.47^{A}$ & $2.93 \pm 0.50^{\mathrm{B}}$ & $2.44 \pm 0.27 \mathrm{C}$ \\
\hline \multirow[t]{3}{*}{$\mathrm{A}(\%)$} & 20 & $4.29 \pm 0.57 \mathrm{~A}$ & $2.99 \pm 0.07 \mathrm{~B}$ & $2.63 \pm 0.09 \mathrm{C}$ \\
\hline & 30 & $4.36 \pm 0.47 \mathrm{~A}$ & $3.13 \pm 0.13^{\mathrm{B}}$ & $2.99 \pm 0.02^{\mathrm{C}}$ \\
\hline & 0.3 & $3.99 \pm 0.06^{\mathrm{A}}$ & $3.10 \pm 0.49^{\mathrm{B}}$ & $2.86 \pm 0.16^{C}$ \\
\hline \multirow[t]{3}{*}{ B $(\%)$} & 0.6 & $4.38 \pm 0.57 \mathrm{~A}$ & $3.15 \pm 0.54^{\mathrm{B}}$ & $2.87 \pm 0.25^{C}$ \\
\hline & 0.9 & $4.02 \pm 0.47 \mathrm{~A}$ & $3.18 \pm 0.52^{\mathrm{B}}$ & $2.93 \pm 0.06^{C}$ \\
\hline & 25 & $4.04 \pm 0.13^{\mathrm{A}}$ & $3.02 \pm 0.24^{\mathrm{B}}$ & $2.55 \pm 0.07 \mathrm{C}$ \\
\hline \multirow[t]{2}{*}{$\mathrm{C}(\mathrm{mg} / \mathrm{kg})$} & 50 & $3.92 \pm 0.18^{\mathrm{A}}$ & $2.91 \pm 0.13^{\mathrm{B}}$ & $2.30 \pm 0.11^{\mathrm{C}}$ \\
\hline & 75 & $3.74 \pm 0.29^{\mathrm{A}}$ & $2.96 \pm 0.37^{\mathrm{B}}$ & $2.51 \pm 0.45^{\mathrm{C}}$ \\
\hline
\end{tabular}

${ }^{*}$ A: Durum buğday unu, B: DATEM, C: L-Askorbik asit (C vitamini)

*A: Durum wheat flour, B: DATEM, C: L-Ascorbic acid (vitamin C)

${ }^{* *}$ Çizelgede, her bir katkı çeșidi için aynı sütunda aynı küçük harflerle gösterilen değerler istatistiksel olarak birbirinden farksızdır ( $p>0.05)$, Depolama süresine göre, sütunlar soldan sağa doğru incelendiğinde aynı büyük harflerle gösterilen değerler istatistiksel olarak birbirinden farksızdır $(p>0.05)$

** In the table, the values indicated by the same small letters in the same column for each additive type are statistically different from each other ( $>>0.05)$, When the columns are examined from left to right according to storage time, the values shown with the same uppercase letters are statistically different from each other $(p>0.05)$ 
Görünüş puanlan üzerine katkıların kullanım düzeylerinin etkisi önemli bulunurken $(p<0.05)$, kullanılan katkıların etkileri istatistiksel olarak önemsiz bulunmuştur $(p>0.05)$. Ekmeklerde görünüss puanları incelendiğinde, bu puanların düzensiz bir değişim gösterdiği gözlenmiştir. Varinli vd. (2002), çeşitli katkı unları kullanarak yaptıkları bazlama ekmeklerinde dış görünüş puanları üzerine mısır unu, çavdar unu, pirinç unu ve yulaf ununun katk1 düzeylerinin önemli bir etkisinin görülmediğini saptamışlardır. Boyacıŏ̆lu (1993), çalışmasında durum buğday unu miktarının \%25 in üzerine çıarnlması ile ekmek puanlarını düşürdüğünü bildirmiştir. Danza vd. (2014) tarafindan yapılan çalışmada da benzer sonuçlar bulunmuştur.

Depolama süresi boyunca tüm katkılı ekmeklerin tekstür puanlannda azalma tespit edilmiştir. Depolama boyunca gözlenen bu azalma istatistiksel olarak da önemli bulunmuştur $(p<0.05)$. Genel olarak bakıldığında tüm depolama süresi boyunca durum buğday unu (A) ve DATEM (B) katk1lı ekmek örnekleri kontrol ve C vitamini (C) katkılı ekmek örneklerine göre daha yüksek tekstür puanlarına sahip olmuşlardır. Toufeili vd. (1995), arap ekmeği üzerine yaptıkları araşurmalarında DATEM'in artan oranlarda ilavesiyle ekmeklerin tekstür puanlarının düştüğünü ifade etmişlerdir. Ayrıca Akın (2015) ve Danza vd. (2014) tarafindan yapilan çalışmalarda elde edilen sonuçlar ile çalışmamızda elde edilen sonuçlar uyum içerisinde bulunmuştur.

Ekmeklerin tat-aroma puanları incelendiğinde katk1ların ve katk1 düzeylerinin etkisi istatistiksel olarak önemsiz bulunmuştur $(p>0.05)$. Yine yapilan istatistiksel analizlerde depolamanin ekmeklerin tat-aroma puanlar1 üzerine etkisinin önemli $(p<0.01)$ olduğu bulunmuştur. Tüm ekmeklerin tat-aroma puanları depolama boyunca azalma göstermiştir (Çizelge 6). Depolama sonunda $50 \mathrm{mg} / \mathrm{kg} \mathrm{C}$ vitamini (C) katkılı ekmek örnekleri dişında tüm katkılı ekmekler kontrole göre daha yüksek puan alırken en yüksek puana 2.99 ile \%30 durum buğday unu (A) kullanılarak yapilan ekmek örnekleri sahip olmuştur. Varinli vd. (2002), soya unu ve misir unu kullanarak ürettikleri bazlama ekmeklerinde \%20 lik katk1 düzeyinin tat-aromada bozulmaya neden olduğunu bildirmişlerdir. Coşkuner ve Karababa (2005), tritikale unu ilavesinin yufka ve lavash ekmeklerinin tat-aroma puanlarını artırdığını saptamışlardır. Başman ve Köksel (1999), bazlama ekmeği üzerine yaptıkları çalışmalarında arpa unu ve buğday kepeği ilavesinin ekmeklerin tat-aroma puanlarını düşürdüğ̈nü bulmuşlardır. Toufeili vd. (1995), araştırmalarında arap ekmeği üretiminde $\% 0.25$ DATEM kullanıldığında duyusal özelliklerin etkilenmediğini ve \%0.50 oranında kullanıldığında ekmek kalitesinin düşük olduğunu ortaya koymuşlardır. Çalışmamızda elde ettiğimiz sonuçlara benzer sonuçlar Akın (2015) ve Danza vd. (2014) tarafindan yapılan çalışmalarda bildirilmiştir.

\section{SONUÇ}

Elde edilen sonuçların incelenmesiyle; durum buğday unu ilavesinin hamurun bazı reolojik özelliklerine olumlu etkisinin diğer katkılara göre daha yüksek olduğu görülmüştür. Özellikle farinograf özelliklerinden stabilite, yoğurma tolerans sayısı ve yumuşama derecesini olumlu yönde etkilediği; ekstensograf özelliklerinden enerji değerini artırdığı, direnç ve maksimum direnç değerlerini artırdığı saptanmıştır. DATEM (B) ve durum buğday unlannın (A) düşük oranlarda kullanılmasının uzama yeteneğini artmasına karşlık, daha yüksek oranlarda düşük uzama yeteneği değerleri saptanmıştır. Ekmeklerde yapılan nem ölçümlerinde genel olarak bakıldığında durum buğday unu ilave edilmiş örnekler depolama süresi boyunca daha yüksek nem değerlerine sahip olmuş ve nem düzeylerindeki düşüş daha az oranda olmuştur. Tekstür özellikleri üzerine DATEM (en yüksek oranının kullanıldığı 48. saat ölçümleri hariç) ve durum buğday ununun yine tüm depolama süresi boyunca olumlu etkide bulunduğu saptanmıştır.

Tüm bu veriler 1şığında, tırnaklı ekmek üretiminde durum buğday ununun belirli oranlarda kullanılabileceği düşünülmektedir. Bölgenin makarnalık buğday yetiştirilmesine elverişli olması da konuya ekonomik bir boyut kazandırmaktadır. Ayrıca bu çalışma, kullanılan katkı maddelerinin değişik kombinasyonlarının da kullanılarak 
tırnaklı ekmek ve benzer tip düz ekmeklerde yapilacak araştırmalara 1şık tutacaktır.

\section{TEŞEKKÜR}

Bu makale Harran Üniversitesi Bilimsel Araştırma Projeleri Birimi tarafindan 408 proje numarası ile desteklenen "Şanlıurfa Yöresine Özgü Tirnaklı (Düz) Ekmeklerde Baz1 Katk1 Maddelerinin Ekmek Kalitesine Etkileri Üzerine Bir Araştırma" başlıklı Yüksek Lisans Tezi esas alınarak hazırlanmıştır.

\section{KAYNAKLAR}

AACC, (2002). Approved Methods of the American Association of Cereal Chemists. Approved Methods of Analyses 10th Edition, The Association: St. Paul, MN.

Aamodt, A., Magnus, E.M., Faergestad, E.M. (2003). Effect of flour quality, ascorbic acid, and DATEM on dough rheological parameters and hearth loaves characteristics. Food Chem Toxicol, 68(7): 2201-2210.

Akın, M.E. (2015). Süne ve kımıl zararı görmüş buğday ununun askorbik asit ve kuvvetli buğday unu paçalıyla "Tırnaklı Ekmek" yapımına uygunluğunun belirlenmesi. Harran Üniversitesi Fen Bilimleri Enstitüsü Gıda Mühendisliği Anabilim Dalı Yüksek Lisans Tezi, Şanlıurfa, Türkiye, $81 \mathrm{~s}$.

Al-Hamdani, H., Altimmemi, S., Ahmed, T., Attea, S. (2019). The use of vitamin C on improving the rheological properties of some weak local wheat varieties. Plant Arch, 19(1): 10751080.

Anonymous, (2013). Türk Gıda Kodeksi Gıda Katkı Maddeleri Yönetmeliği. Resmi Gazete, 30 Haziran 2013, Say1: 28693.

Baiano, A., Terracone, C. (2011). Dough rheology and bread quality of supplemented flours. CYTAJ Food, 9(3): 180-186.

Baratto, C., Becker, N.B., Gelinski, J.M.L.N., Silveria, S.M. (2015). Influence of enzymes and ascorbic acid on dough rheology and wheat bread quality. Afr J Biotechnol, 14(46): 3124-3130.

Başman, A., Köksel, H. (1999). Properties and composition of Turkish flat bread (Bazlama) supplemented with barley flour and wheat bran. Cereal Chem, 76: 506-511.

Basman, A., Köksel, H. (2001). Effect of barley flour and wheat bran supplementation on the properties and composition of Turkish flat bread, Yufka. Eur Food Res Technol, 212:198-202.

Boyacıŏlu, M.H. (1993). Durum buğdayı ve ekmeklik buğday unu karışımlanının bazı katkı maddeleriyle birlikte ekmek yapımında kullanımı. Makarnalık Buğday ve Mamülleri Simpozyumu, 30 Kasım-3 Aralık 1993, Ankara, Türkiye, s 352365.

Cingöz, A. (2018). Hidrotermal işlem görmüş kepeklerin ekmek kalitesi ve besleyicilik değerine etkisi. Tokat Gaziosmanpaşa Üniversitesi Fen Bilimleri Enstitüsü Gıda Mühendisliği Anabilim Dalı Doktora Tezi, Tokat, Türkiye, 177 s.

Cosskuner, Y., Karababa, E. (2005). Studies on the quality Turkish flat breads based on blends of triticale and wheat flour. Int J Food Sci Technol, 40: 469-479.

Coşkuner, Y. (1993). Çukurova bölgesinde yetiştirilen bazı buğday çeşitlerinin tek ve iki katlı düz ekmek üretimine uygunluğu ile ekşi hamurun kalite üzerine etkisinin araştırılması. Ankara Üniversitesi Fen Bilimleri Enstitüsü Gıda Mühendisliği Anabilim Dalı Doktora Tezi, Ankara, Türkiye 149 s.

Çelik, S., Sivri, D., Köksel, H. (2000). Bazı katkı maddelerinin ekmek özellikleri üzerine etkisi. GID A, 26(1): 3-8.

Danza, A., Mastromatteo, M., Cozzolino, F., Lecce, L., Lampignano, V., Laverse, J., Alessandra Del Nobile, M. (2014). Processing and characterization of durum wheat bread enriched with antioxidant from yellow papper flour. $L W T$ Food Sci Technol, 59: 479-485.

Demir, M.K., Elgün, A., Argun, M.Ş. (2009). Sütçülük yan ürünlerinden peynir altı, yayık altı ve süzme yoğurt suları katkılarının bazı ekmek özelliklerine etkileri üzerine bir araştırma. GID $A$, 34(2): 99-106.

Ding, S., Yang, J. (2013). The influence of emulsifiers on the rheological properties of wheat 
flour dough and quality of fried instant noodles. LWT-Food Sci Technol, 53: 61-69.

Dizlek, H., Çimer, H., Altan, A. (2013). Vital buğday gluteninin ve L-askorbik asidin buğday kepekli ekmeklerin bazı nitelikleri üzerine etkileri. GID A, 38(2): 87-94.

Dizlek, H., Gül, H. (2007). L-askorbik asit ve ekmekçilikteki işlevleri. Süleyman Demirel Üniversitesi Ziraat Fakültesi Dergisi, 2(1): 26-34. ISSN 1304-998.

Farvili, N., Walker, C.E., Qarooni, J. (1995). The effect of protein content of flour and emulsifiers on tanoor bread quality. J Cereal Sci, 26: 137-143.

Gaupp, R., Adams, W. (2014). Diacetyl tartaric esters of monoglycerides (DATEM) and associated emulsifiers in bread making. Emuls Food Technol, 121-146.

Hatcher, D.W., Dexter, J.E., Anderson, M.J., Bellido, G.G., Fu, B.X. (2009). Effect of blending durum wheat flour with hard white wheat flour on the quality of yellow alkaline noodles. Food Chem, 113: 980-988.

ICC, 2002. Standard Methods of The International Association for Cereal Science and Technology (ICC). Printed by ICC, Vienna, Edition 2002.

Karatekin, E. (2008). Süne zaranna uğramış buğday ununun katk1 maddeleri kullanilarak ekmeklik kalitesinin iyileştirilmesi. Çukurova Üniversitesi Fen Bilimleri Enstitüsü Gıda Mühendisliği Anabilim Dalı Yüksek Lisans Tezi, Adana, Türkiye $62 \mathrm{~s}$.

Kaur, A., Singh, N., Kaur, S., Katyal, M., Virdi, A.S., Kaur, D., Ahlawat, A.K., Singh, A.M., (2015). Relationship of various flour properties with noodle making characteristics among durum wheat varieties. Food Chem, 188: 517-526.

Köten, M., Ünsal, A.S. (2007). Şanlıurfa yöresine özgü "Tırnaklı ve Açık Ekmeklerin" geleneksel üretim yöntemleri. GID $A$, 32(2): 81-85.

Ma, S., Li, L., Wang, X., Zheng, X., Bian, K., Bao, Q. (2016). Effect of mechanically damaged starch from wheat flour on the quality of frozen dough and steamed bread. Food Chem, 202: 120-124.
Özer, M.S., Altan, A. (1995). Küçük ekmek yapımında bazı katkı maddelerinin kullanılmasının ekmek nitelikleri üzerindeki etkileri. GID A, 20(6): 357-363.

Pasqualone, A., Laddomada, B., Centomani, I., Paradiso, V.M., Minervini, D., Caponio, F., Summo, C. (2017). Bread making aptitude of mixtures of re-milled semolina and selected durum wheat milling by-products. LWT-Food Sci Technol, 78: 151-159.

Qarooni, J., Posner, E.S., Ponte, Jr.J.G. (1993). Production of tanoor bread with hard white and other U.S. wheats. Lebens Wissench Tecbnol, 26: 100106.

Rasper, V.F., Preston, K.R. (1991). The Extensograph Handbook, Published by The AACC, Inc. St. Paul Minnesota, U.S.A, 46 p.

Ravi, R., Manohar, R.S., Rao, P.H. (2000). Influence of additives on the rheological characteristics and baking quality of wheat flours. Eur Food Res Technol, 210: 202-208.

Sayaslan, A., Koyuncu, M., Türker, S., Irklı, Y., Serin, A., Orhan, F.G. (2018). Use of durum wheat clear flour in vital gluten and bioethanol production. J Cereal Sci, 80: 50-56.

SPSS INC. (1998). SPSS Professional Statistics, 10.0, SPSS inc., Chicago.

Sungur, B. (2018). The use of hydrocolloids in bread-making. J Tour Gastron Stud, 6(1): 41-53.

Sungur, B., Ercan, R. (2011). Effects of some hydrocolloids and surfactant on the rheological properties of hard wheat flour dough by using response surface methodology. GID $A, 36$ (2): 77 82.

Torbicaa, A., Hadnadev, M., Hadnadev, T.D. (2011). Possibility of using durum wheat flour as an improvement. Procedia Food Sci, 1: 1628-1632.

Toufeili, I., Shadarevian, S., Adnan, M.A., Hani, I. (1995). Effect of shortening and surfactants on selected chemical/physicochemical parameters and sensory quality of arabic bread. Food Chem, 53:253-258. 
Uluöz, M. (1965). Buğday, Un ve Ekmek Analiz, Metodlar. Ege Üniversitesi, Ziraat Fak. Yayınları, İzmir, 71s.

Xiujin, Z., Jinguan, S., Zaigui, L. (2007). Effects of DATEM on dough rheological characteristics and qualities of CSB and bread. Cereal Chem, 84(2):181-185.
Varinli, A, Kırıt A.B., Coşkuner, Y., Karababa, E. (2002). Çeşitli katkı unlarının bazlama ve yufka ekmeklerinin duyusal özellikleri üzerine etkisi. Hububat Ürünleri Teknolojisi Kongre ve Sergisi, 3-4 Ekim, Gaziantep, s 593-603. 